\title{
Caspase- 2 is involved in cell death induction by taxanes in breast cancer cells
}

Michael Jelínek', Kamila Balušíková', Dana Kopperová', Vlasta Němcová-Fürstová1, Jan Šrámek1, Julie Fidlerová1, Ilaria Zanardi ${ }^{2}$, Iwao Ojima ${ }^{2}$ and Jan Kovár ${ }^{{ }^{*}}$

\begin{abstract}
Background: We studied the role of caspase-2 in apoptosis induction by taxanes (paclitaxel, novel taxane SB-T-1216) in breast cancer cells using SK-BR-3 (nonfunctional p53, functional caspase-3) and MCF-7 (functional p53, nonfunctional caspase-3) cell lines.

Results: Both taxanes induced apoptosis in SK-BR-3 as well as MCF-7 cells. Caspase-2 activity in SK-BR-3 cells increased approximately 15 -fold within $48 \mathrm{~h}$ after the application of both taxanes at the death-inducing concentration (100 nM). In MCF-7 cells, caspase-2 activity increased approximately 11-fold within $60 \mathrm{~h}$ after the application of taxanes (300 nM). Caspase-2 activation was confirmed by decreasing levels of procaspase-2, increasing levels of cleaved caspase-2 and the cleavage of caspase-2 substrate golgin-160. The inhibition of caspase-2 expression using siRNA increased the number of surviving cells more than 2-fold in MCF-7 cells, and at least 4-fold in SK-BR-3 cells, $96 \mathrm{~h}$ after the application of death-inducing concentration of taxanes. The inhibition of caspase-2 expression also resulted in decreased cleavage of initiator caspases (caspase-8, caspase-9) as well as executioner caspases (caspase-3, caspase-7) in both cell lines after the application of taxanes. In control cells, caspase-2 seemed to be mainly localized in the nucleus. After the application of taxanes, it was released from the nucleus to the cytosol, due to the long-term disintegration of the nuclear envelope, in both cell lines. Taxane application led to some formation of PIDDosome complex in both cell lines within $24 \mathrm{~h}$ after the application. After taxane application, P21 ${ }^{\text {WAF1/CIP1 }}$ expression was only induced in MCF-7 cells with functional p53. However, taxane application did not result in a significant increase of PIDD expression in either SK-BR-3 or MCF-7 cells. The inhibition of RAIDD expression using siRNA did not affect the number of surviving SK-BR-3 and MCF-7 cells after taxane application at all.

Conclusion: Caspase-2 is required, at least partially, for apoptosis induction by taxanes in tested breast cancer cells. We suggest that caspase-2 plays the role of an apical caspase in these cells. Caspase-2 seems to be activated via other mechanism than PIDDosome formation. It follows the release of caspase-2 from the nucleus to the cytosol.
\end{abstract}

Keywords: Caspase-2, Cell death, Taxanes, Breast cancer cells

\section{Background}

Taxanes represent a well-known but relatively new group of anticancer drugs. There are two established (classical) taxanes, paclitaxel $\left(\right.$ Taxol $\left.^{\circ}\right)$ and docetaxel (Taxotere $\left.{ }^{\circ}\right)$, currently used for treatment of breast and ovarian cancer as well as head and neck, lung and prostate cancer [1,2]. In addition to the aforementioned classical taxanes, novel taxanes have been developed. They represent a new generation of taxoids (taxane analogs). They are not yet used

\footnotetext{
* Correspondence: jan.kovar@lf3.cuni.cz

'Department of Cell and Molecular Biology, Third Faculty of Medicine,

Charles University, Ruská 87, 100 00, Prague 10, Czech Republic

Full list of author information is available at the end of the article
}

in clinical practice but they are substantially more effective in resistant cancer cells in vitro and in vivo [3-7].

Taxanes are mitotic poisons. They bind to the $\beta$ subunit of the tubulin heterodimer, thereby stabilizing microtubules and inhibiting their depolymerization [8-10]. In this way, taxanes are thought to block progression through the M-phase of the cell cycle $[9,11]$. However, the relationship between mitotic arrest and the induction of cell death by taxanes remains unclear [12-14].

The molecular mechanism of cell death induction by taxanes is not fully understood either. It has been

\section{Biomed Central}

(c) 2013 Jelínek et al.; licensee BioMed Central Ltd. This is an Open Access article distributed under the terms of the Creative Commons Attribution License (http://creativecommons.org/licenses/by/2.0), which permits unrestricted use, distribution, and reproduction in any medium, provided the original work is properly cited. 
previously shown that apoptosis induced by taxanes seems to be p53 independent $[4,15]$. On the other hand, several findings concerning cytochrome c release, caspase- 9 activation and caspase- 3 activation strongly indicate, that at least in some cases, a mitochondrial pathway is involved in apoptosis induction by taxanes [4,16,17]. However, alternative nonmitochondrial pathways could also be involved $[4,7,18]$, including caspase- 8 activation $[7,14,19]$. Recently, the role of caspase- 2 in apoptosis induction by taxanes has come under consideration [7,14,20,21].

Caspase-2 is ubiquitously expressed and represents an evolutionarily highly conserved mammalian caspase. However, its precise physiological function has not been identified. Several lines of evidence point to caspase- 2 as a major player in apoptosis induction [22,23]. Procaspase-2 interacts with other proteins, such as CARD-containing RAIDD protein, via its caspase recruitment domain (CARD). RAIDD interacts with another death domain containing protein PIDD via its death domain [24]. The complex of procaspase-2, RAIDD and PIDD, known as PIDDosome, facilitates caspase- 2 activation. PIDD is a p53-inducible protein $[23,25]$. In some cases, PIDD seems to function as a regulator of caspase-2 activity [26]. However, caspase-2 activation independent of p53, as well as RAIDD and PIDD, has also been reported, e.g. in cases of cell death via a mitotic catastrophe [27-30]. Caspase-2 has been found in the cytosol, Golgi complex and mitochondria. It is also present in the nucleus. Active caspase- 2 specifically cleaves golgin-160 which is present in the Golgi complex [31].

It has been suggested that caspase- 2 functions as the most apical caspase when apoptosis is induced by DNA damage and cytotoxic stress [32,33]. The involvement of caspase- 2 activation in apoptosis of breast cancer cells, induced by various stimuli, has also been found [27,34-36]. Several other studies have also demonstrated caspase-2 activation in various types of cancer cells following apoptosis induction by taxanes $[21,37,38]$.

We have previously found that caspase- 2 is significantly activated in breast cancer cells (together with the activation of caspase-3, caspase- 9 and caspase-8) following apoptosis induction by taxanes $[7,14]$. We have also shown that the mitochondrial pathway is not, at least in some cases, the predominant pathway of apoptosis induction by taxanes in breast cancer cells, and that caspase-2 may be a major player in this process [7]. In our present study, we investigated the role of caspase- 2 in apoptosis induction by taxanes in breast cancer cells. We used breast cancer cells SK-BR-3 (nonfunctional p53, functional caspase-3) and MCF-7 (functional p53, nonfunctional caspase-3) as an experimental model and tested both classical (paclitaxel) and novel (SB-T-1216) taxanes. We demonstrated that caspase- 2 is required for apoptosis induction by taxanes in the tested breast cancer cells, probably as an apical caspase. Caspase-2 is activated via other mechanism than PIDDosome formation.

\section{Results}

\section{Effect of taxanes on growth and survival}

The effects of paclitaxel and SB-T-1216 on growth and survival of SK-BR-3 cells were tested over a wide range of concentrations (0.3-1000 nM). Paclitaxel and SB-T-1216 both induced death of SK-BR-3 cells within $96 \mathrm{~h}$ of incubation at a concentration of $30 \mathrm{nM}$ and higher concentrations. The $\mathrm{C}_{50}$ values (concentration of taxanes resulting in $50 \%$ living cells compared to controls after $96 \mathrm{~h}$ of incubation) were $15 \mathrm{nM}$ and $3 \mathrm{nM}$ for paclitaxel and SB$\mathrm{T}-1216$, respectively (Figure 1 ).

In the case of MCF-7, the effects of taxanes were also tested over a wide range of concentrations (0.3-3000 nM). Both paclitaxel and SB-T-1216 induced the death of MCF7 cells within $96 \mathrm{~h}$ of incubation at a concentration of 100 $\mathrm{nM}$ and higher concentrations. The $\mathrm{C}_{50}$ values of paclitaxel and SB-T-1216 were similar, $5 \mathrm{nM}$ and $8 \mathrm{nM}$, respectively (Figure 1).

The data showed that MCF-7 cells were more resistant to cell death induction by both taxanes at higher concentrations (30 nM and higher concentrations) than SK-BR-3 cells. In MCF-7 cells, paclitaxel and SB-T-1216 exerted similar effects. However, in SK-BR-3 cells, SB-T-1216 seemed to be more efficient than paclitaxel (Figure 1).

On the basis of our data, we selected $100 \mathrm{nM}$ and 300 $\mathrm{nM}$ as the cell death-inducing concentrations, i.e. the lowest concentration having complete death-inducing effect, of tested taxanes for SK-BR-3 cells and MCF-7 cells, respectively. These concentrations were used in subsequent experiments.

\section{Effect of taxanes on caspase-2 activity}

Employing a commercial kit and flow cytometry (see "Materials and Methods"), we tested the time course of caspase-2 activation in both SK-BR-3 and MCF-7 cells after taxane application.

Caspase-2 activity in SK-BR-3 cells increased within $48 \mathrm{~h}$ after the application of paclitaxel and SB-T-1216 at death-inducing concentrations (100 nM) approximately 16-fold and 14-fold, respectively. A substantial increase (approximately 10-fold for both taxanes) was seen $36 \mathrm{~h}$ after taxane application as well as a noticeable increase (about 3-fold) $24 \mathrm{~h}$ after application (Figure 2).

In the case of MCF-7 cells, caspase- 2 activity increased within $60 \mathrm{~h}$ after the application of both taxanes at deathinducing concentrations (300 nM) approximately 11-fold. A significant increase (approximately 4-fold for both taxanes) was seen $48 \mathrm{~h}$ after taxane application and a noticeable increase (about 2-fold) $36 \mathrm{~h}$ after application (Figure 2).

In order to confirm caspase- 2 activation, we assessed the cleavage of procaspase- 2 by measuring the level of 


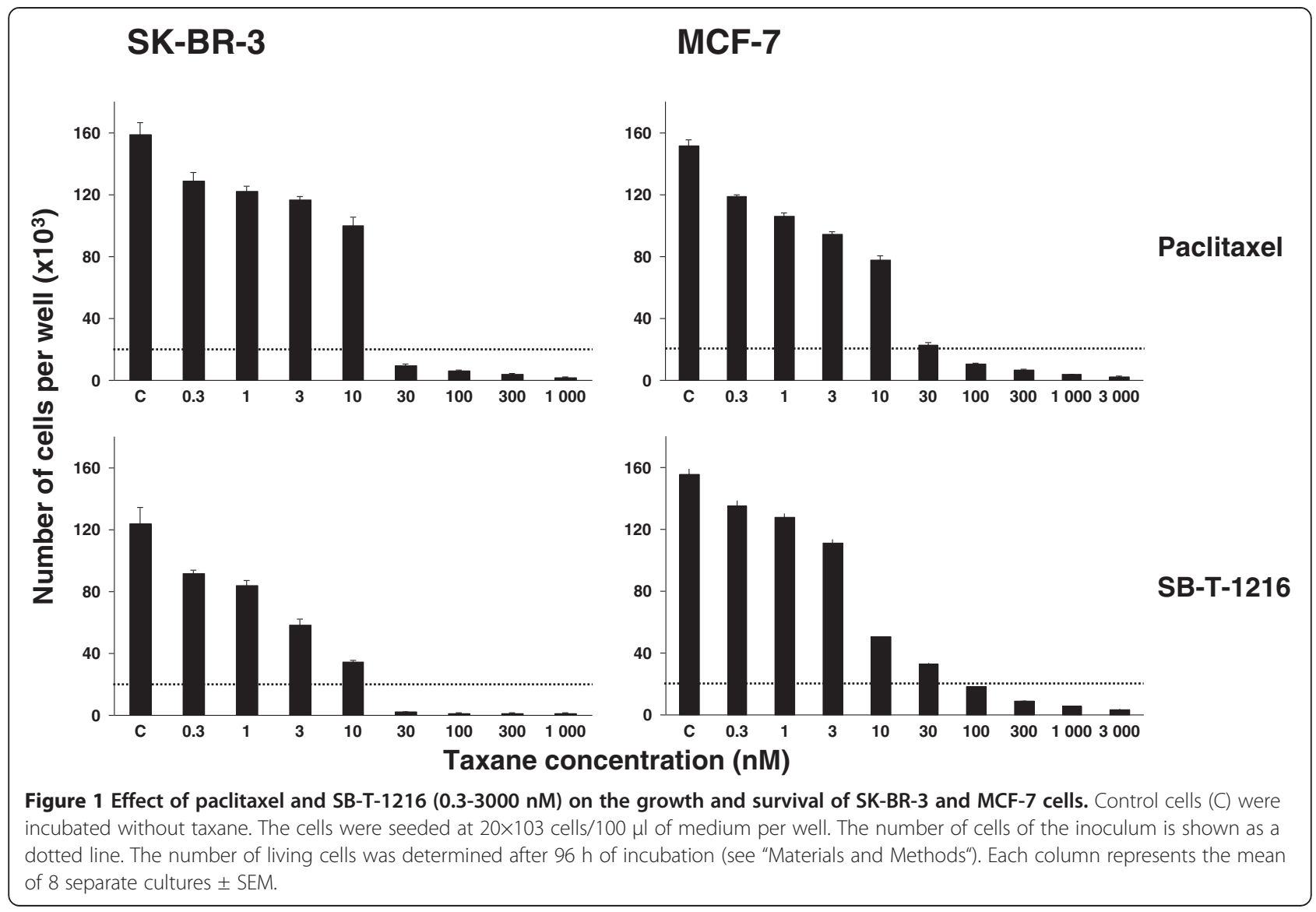

procaspase-2 using western blot analysis. Procaspase-2 level decreased significantly $36 \mathrm{~h}$ after the application of both taxanes in SK-BR-3 cells. After $48 \mathrm{~h}$, the level of procaspase-2 in SK-BR-3 cells was very low (Figure 3A). Concerning MCF-7 cells, some decrease in procaspase- 2 level was seen $24 \mathrm{~h}$ after taxane application, but a more significant decrease was seen $36 \mathrm{~h}$ and $48 \mathrm{~h}$ after application. After $60 \mathrm{~h}$, the level of procaspase- 2 in MCF-7 cells was very low (Figure 3A).

Decreasing procaspase-2 level points at procaspase-2 cleavage resulting from formation of active caspase- 2 . The decrease of procaspase-2 level in SK-BR-3 cells correlated with increased level of the cleaved form $36 \mathrm{~h}$ after taxane application. However, $48 \mathrm{~h}$ after taxane application cleaved caspase-2 disappeared (Figure 3A). Similarly, the decrease of procaspase- 2 level in MCF-7 cells correlated with increased level of the cleaved form $36 \mathrm{~h}$ and $48 \mathrm{~h}$ after taxane application. Again, $60 \mathrm{~h}$ after taxane application we can see decreasing level of cleaved caspase-2 (Figure 3A).

The levels of caspase- 2 substrate golgin-160 using western blot analysis were also assessed. A significant decrease in golgin-160 level corresponded with decreased procaspase-2 level in both SK-BR-3 and MCF-7 cells after application of both taxanes (Figure 3A,B).
Effect of the inhibition of caspase- 2 expression on taxane induced cell death

Employing RNA interference (see "Materials and Methods"), we assessed the effect of specific inhibition of caspase-2 expression on cell death induction after taxane application.

First, the efficiency of the RNA interference was tested. The inhibition of caspase- 2 expression was about $80 \%$ compared to control (Figure 4A) in SK-BR-3 cells and more than $80 \%$ in MCF-7 cells (Figure 4A). Moreover, nonsense siRNA or specific caspase-2 siRNA did not significantly affect cell growth or survival in either cell line. However, cells transfected with siRNAs seemed to grow slightly slowlier in comparison with control (Figure 4B).

After $48 \mathrm{~h}$ of incubation with taxanes at death-inducing concentrations $(100 \mathrm{nM})$, the inhibition of caspase- 2 expression resulted in an approximately 2 -fold increase in the number of surviving SK-BR-3 cells. It represents a statistically significant increase from $26 \%$ to $60 \%$ of the original number of cells for paclitaxel and from $33 \%$ to $64 \%$ for SB-T-1216. After $96 \mathrm{~h}$, the effect was even more pronounced. In the case of paclitaxel, the number of surviving SK-BR-3 cells increased from $4 \%$ to $30 \%$ and from $7 \%$ to $26 \%$ for SB-T-1216 (Figure $4 \mathrm{C}$ ).

As for MCF-7 cells, the inhibition of caspase-2 expression, after the application of both paclitaxel and SB-T-1216 


\section{SK-BR-3}

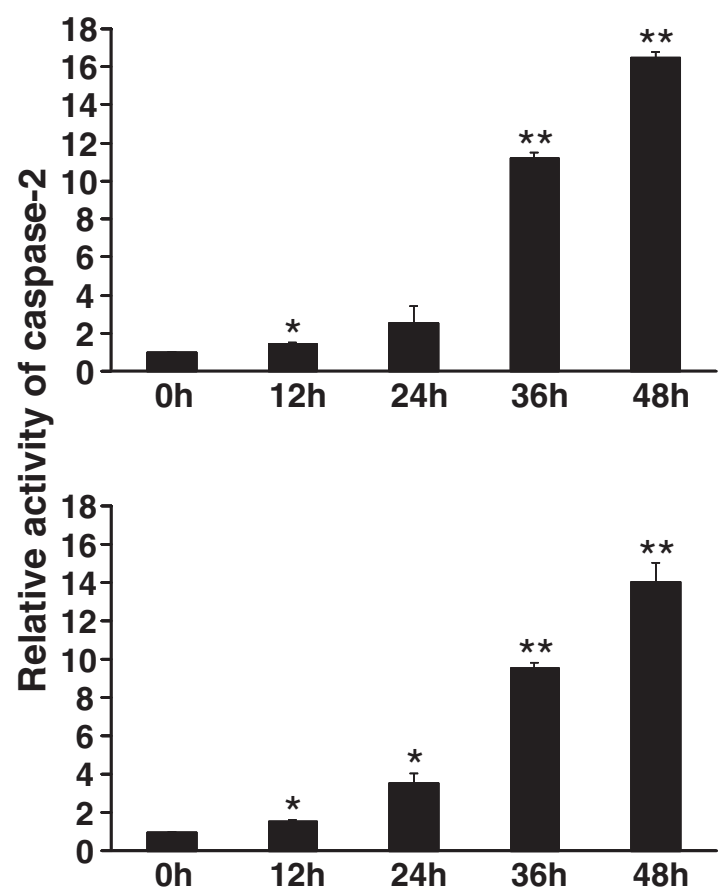

\section{MCF-7}
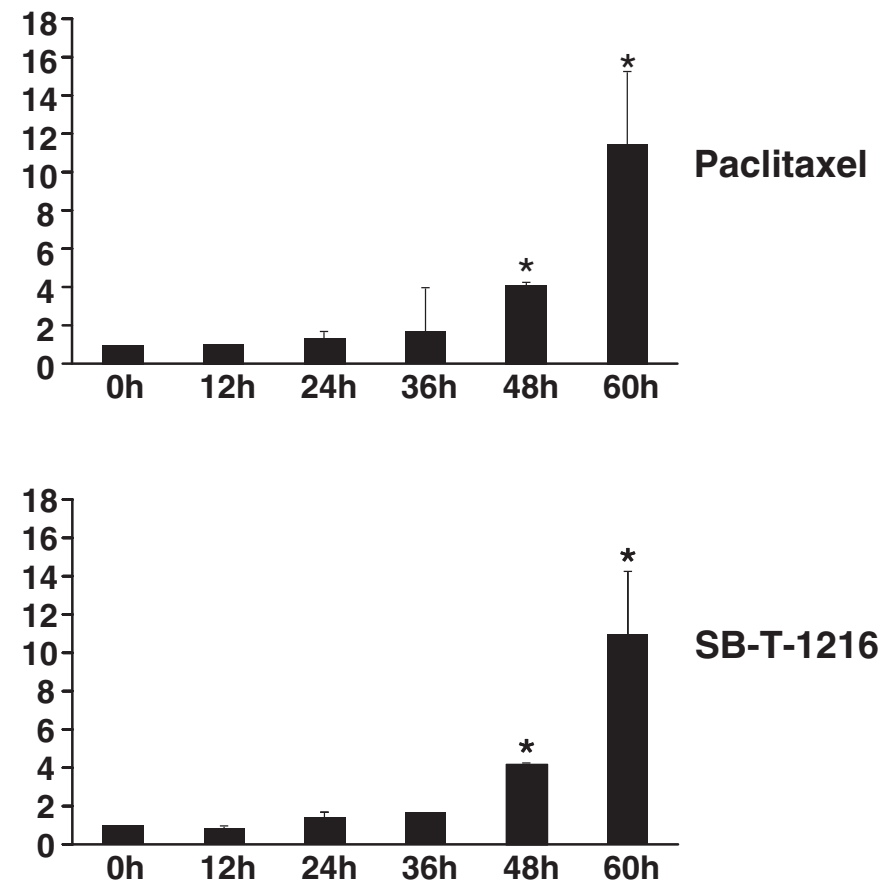

Figure 2 Effect of paclitaxel and SB-T-1216 on the activity of caspase-2 in SK-BR-3 and MCF-7 cells. After 0, 12, 24, 36, 48 and 60 h of incubation with paclitaxel or SB-T-1216 (100 nM for SK-BR-3 cells and 300 nM for MCF-7 cells), the activity of caspase-2 was measured by flow cytometry employing CaspGLOWTM Active Caspase Staining Kit (see "Materials and Methods"). Mean fluorescence at $0 \mathrm{~h}$ was 23.9 for SK-BR-3 cells and 28.5 for MCF-7 cells. Each column represents the mean of 2 experimental values \pm SEM. ${ }^{*} \mathrm{P}<0.05$, ${ }^{* *} \mathrm{P}<0.01$ when comparing the effect with that at $0 \mathrm{~h}$.

at death-inducing concentrations $(300 \mathrm{nM})$, increased the number of surviving cells roughly 2 -fold after $48 \mathrm{~h}$ and $96 \mathrm{~h}$ of incubation. After $48 \mathrm{~h}$ of incubation, there was a statistically significant increase from $96 \%$ to $203 \%$ of the original number of cells for paclitaxel and from $78 \%$ to $147 \%$ for SB-T-1216. After $96 \mathrm{~h}$, the number of surviving cells increased from $42 \%$ to $112 \%$ and from $50 \%$ to $121 \%$ for paclitaxel and SB-T-1216, respectively (Figure 4C). It was also a statistically significant increase. These data demonstrate that MCF-7 cells grew even after application of both taxanes at death-inducing concentrations when caspase-2 expression was inhibited (Figure 4C).

Effect of the inhibition of caspase- 2 expression on taxane induced activation of caspase-8, $-9,-3$ and -7

Using siRNA technique (see "Materials and Methods"), we also assessed the effect of specific inhibition of caspase- 2 expression on the activation of caspase- $8,-9,-3$ and -7 after taxane application.

SK-BR-3 cells with suppressed expression of caspase-2 (for the efficiency see previous section) were incubated with paclitaxel or SB-T-1216 (100nM) for 24 h. Subsequent western blot analysis showed significantly decreased cleavage of caspase- 9 and caspase- 3 due to inhibition of caspase-2 expression. No considerable change in the level of cleaved caspase- 8 was observed. Surprisingly, the level of cleaved caspase-7 significantly increased (Figure 5).

MCF-7 cells (without functional caspase-3) with inhibited expression of caspase- 2 were incubated with tested taxanes (300nM) for $48 \mathrm{~h}$. Western blot analysis showed significantly decreased levels of cleaved caspase- 8 and cleaved caspase-9. Decreased level of cleaved caspase-7 was not as pronounced (Figure 5).

\section{Effect of taxanes on cellular distribution of caspase-2}

The effect of tested taxanes on cellular distribution of caspase-2 was assessed using confocal microscopy (see "Materials and Methods").

Confocal microscopy showed that caspase-2 (detected by two different antibodies) seemed to be mainly found in the nucleus of control SK-BR-3 cells. However, caspase-2 did not colocalize with DNA, as we demonstrated when comparing interphase and mitotic control cells. After $36 \mathrm{~h}$ of incubation with paclitaxel or SB-T-1216 at deathinducing concentrations (100 $\mathrm{nM})$, caspase- 2 was released from the nucleus to the cytosol. This was probably due to the mitotic block following taxane application which is associated with the disintegration of the nuclear envelope 


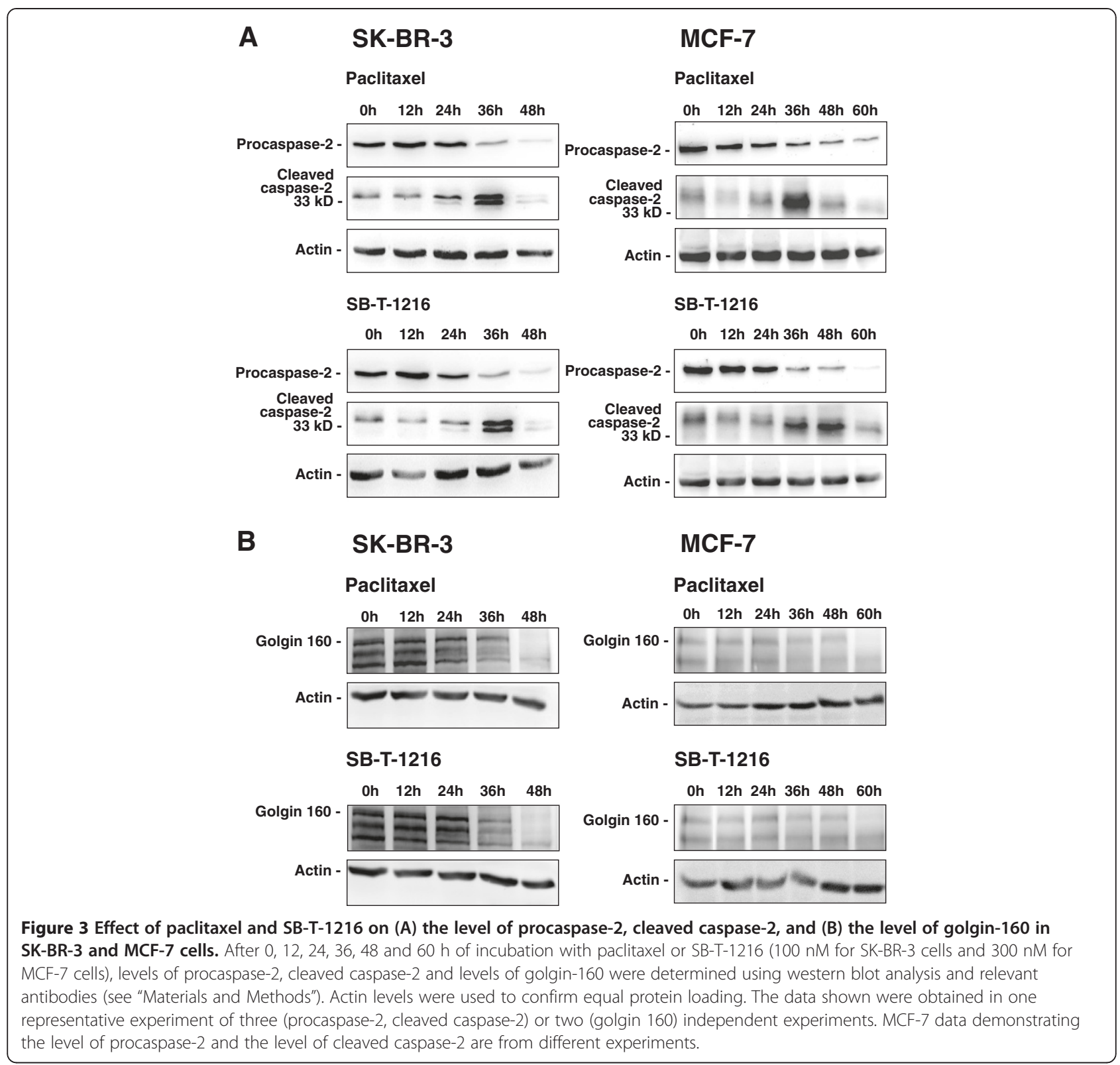

(Figure 6). However, caspase-2 was not redistributed into mitochondria (data not shown). Similar data were obtained with MCF-7 cells (data not shown).

\section{Effect of taxanes on p53 activation}

We assessed the activation of p53 by induction of p $21^{\text {WAF1/CIP1 }}$ expression employing real-time PCR (mRNA level) and western blot analysis (protein level).

Within 36-h incubation of SK-BR-3 cells (nonfunctional p53) with paclitaxel at the death-inducing concentration $(100 \mathrm{nM})$, the level of $\mathrm{p} 21^{\mathrm{WAF} 1 / \mathrm{CIP1}}$ mRNA decreased to $40 \%$ of the original value (statistically significant decrease). Western blot analysis did not detect any p21 ${ }^{\text {WAF1/CIP1 }}$ protein in these cells during $36 \mathrm{~h}$ of incubation with the taxane (Figure 7). Similar data were obtained with SBT-1216 in SK-BR-3 cells (data not shown).

With regard to MCF-7 cells (functional p53), p21 WAF1/CIP1 mRNA level increased approximately 9-fold during $36 \mathrm{~h}$ of incubation with paclitaxel at the death-inducing concentration $(300 \mathrm{nM})$. This pronounced and statistically significant increase of $\mathrm{p} 21^{\mathrm{WAF} 1 / \mathrm{CIP} 1}$ mRNA level corresponded to a pronounced increase in $\mathrm{p} 21^{\mathrm{WAF} 1 / \mathrm{CIP} 1}$ protein level (Figure 7). Again, similar data were obtained with SB-T-1216 in these cells (data not shown).

\section{Effect of taxanes on PIDD expression}

Effect on PIDD expression was assessed using real-time PCR (mRNA level) and western blot analysis (protein level). 


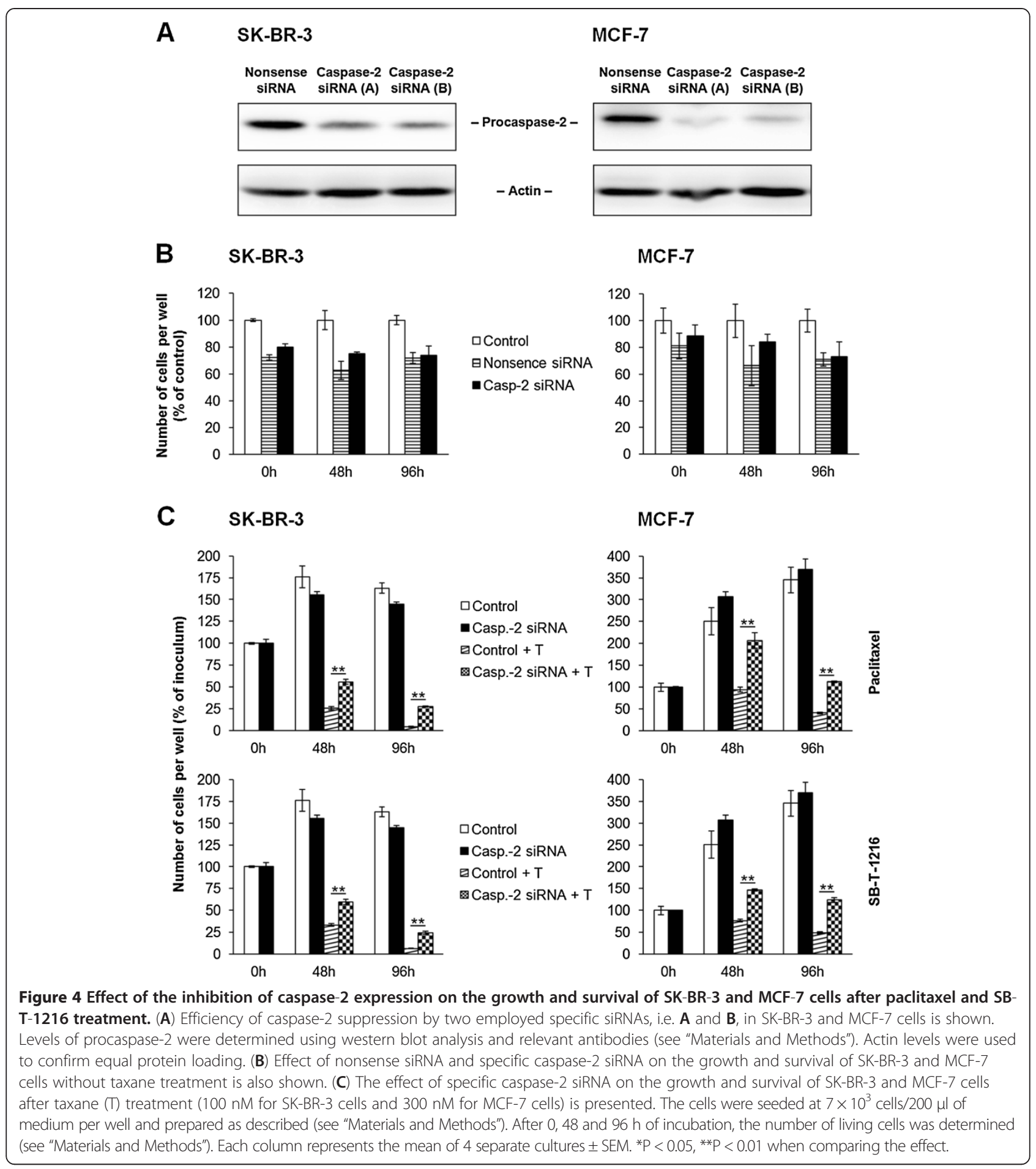

The level of PIDD mRNA showed a decrease (to $60 \%$ of the original value) during 36-h incubation of SK-BR-3 cells with paclitaxel at the death-inducing concentration (100 $\mathrm{nM})$. PIDD protein level also seemed to decrease slightly after $36 \mathrm{~h}$ of incubation with paclitaxel (Figure 8). Similar data were obtained with SB-T-1216 (data not shown).
PIDD mRNA in MCF-7 cells showed similar levels during 36-h incubation with paclitaxel at the deathinducing concentration (300 nM). No significant change was found for PIDD protein level (Figure 8). As was the case for SK-BR-3 cells, similar data were obtained with SB-T-1216 (data not shown). 


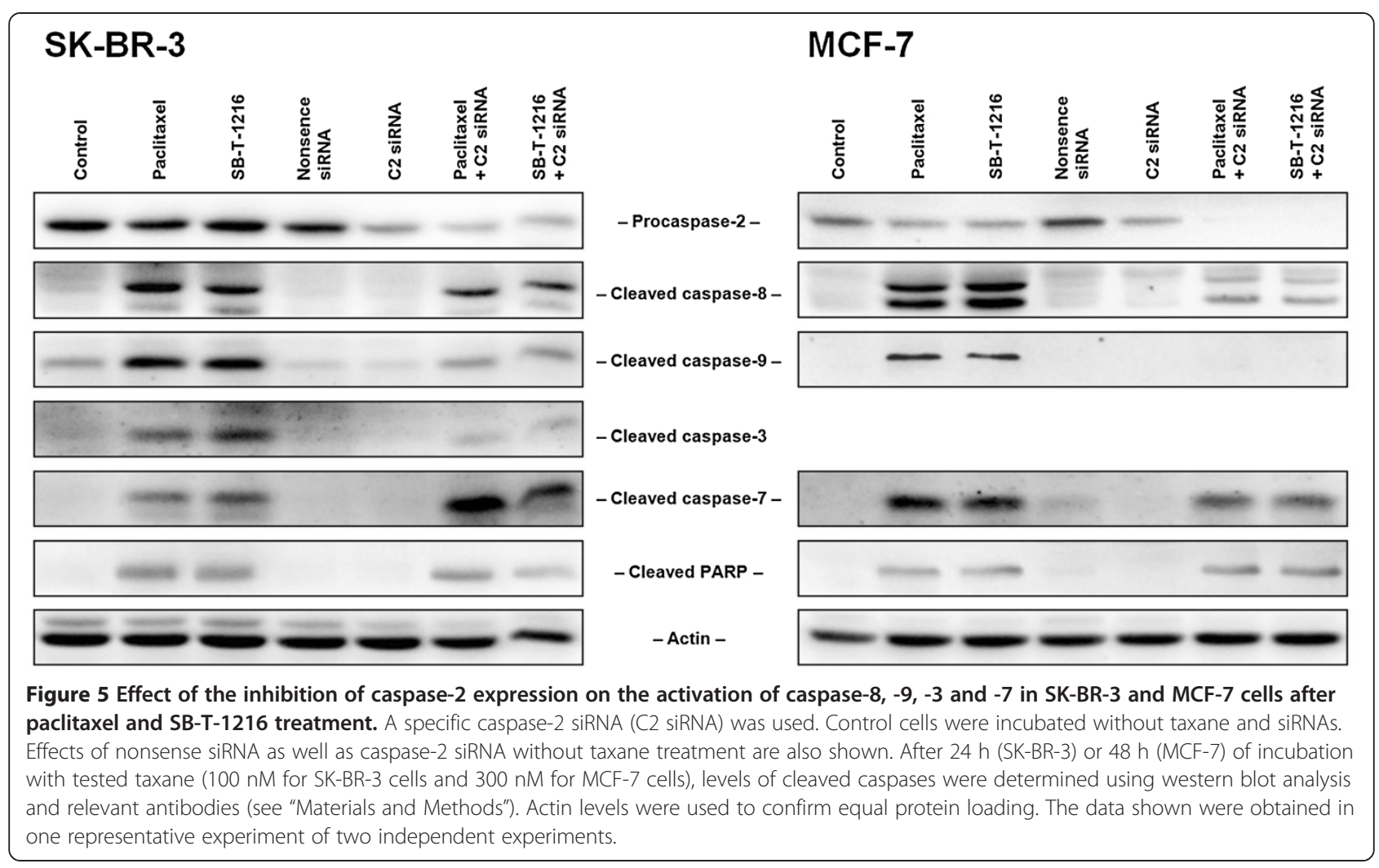

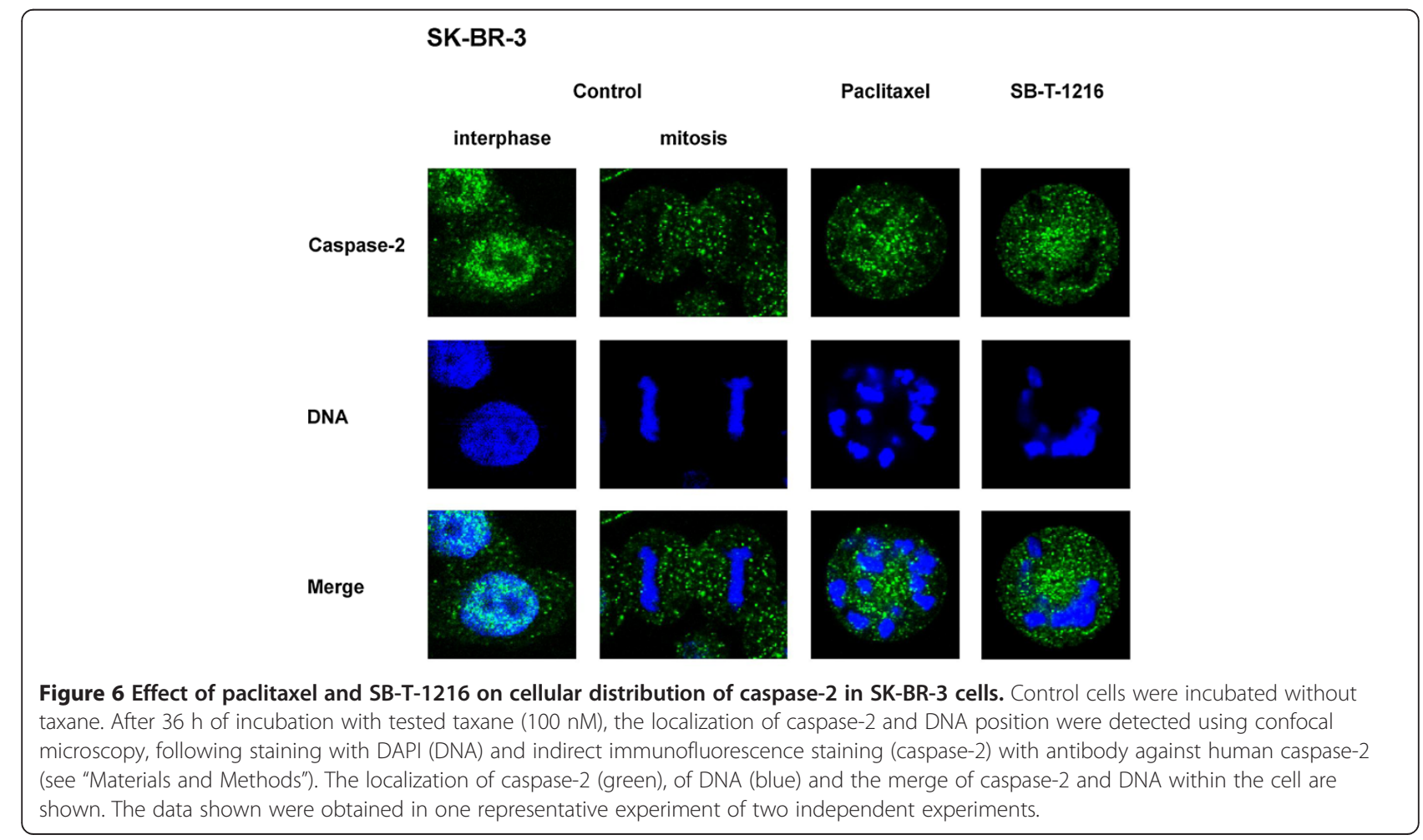




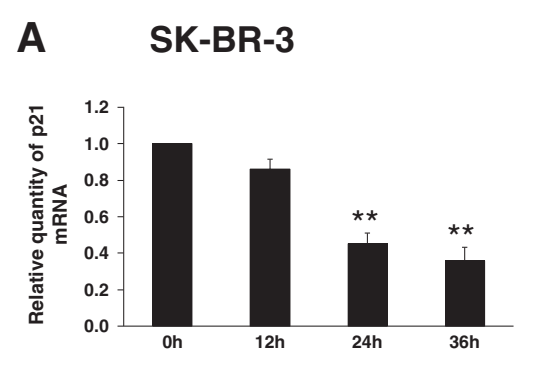

B

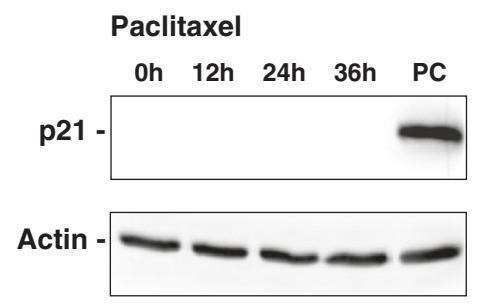

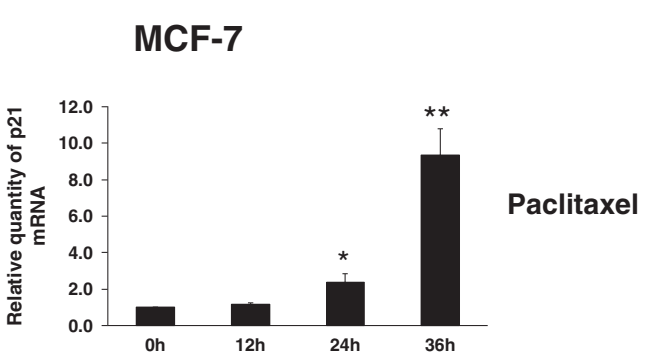

MCF-7

Paclitaxel

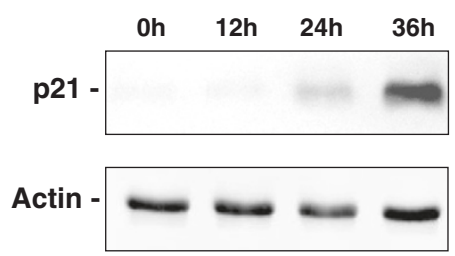

Figure 7 Effect of paclitaxel on the level of (A) p2 ${ }^{\text {WAF1/CIP1 }}$ mRNA and (B) p21 WAF1/CIP1 protein in SK-BR-3 and MCF-7 cells. After 0, 12 , 24 and $36 \mathrm{~h}$ of incubation with paclitaxel (100 nM for SK-BR-3 cells and $300 \mathrm{nM}$ for MCF-7 cells), the level of mRNA was determined using RT-PCR and relevant primers and the level of protein was determined using western blot analysis and relevant antibodies (see "Materials and Methods"). Each column of mRNA data represents the mean of 4 experimental values \pm SEM. ${ }^{*} \mathrm{P}<0.05$, ${ }^{*} \mathrm{P}<0.01$ when comparing the effect with that at $0 \mathrm{~h}$. Actin levels of protein data were used to confirm equal protein loading. In the case of SK-BR-3 cells, MCF-7 cells after $36 \mathrm{~h}$ of incubation with paclitaxel were used as a positive control (PC). The data shown were obtained in one representative experiment of two independent experiments.

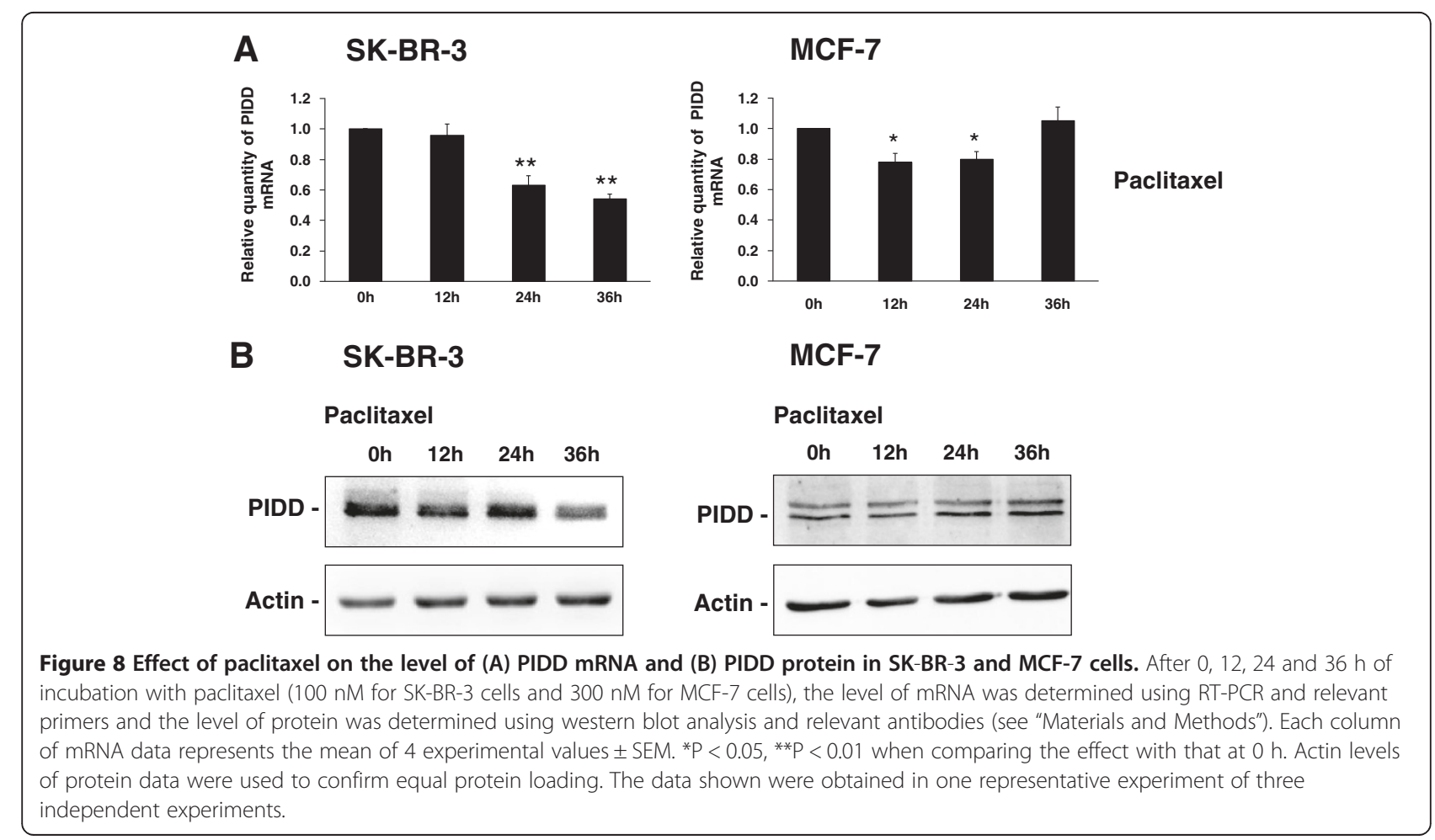


Similar data were obtained, when PIDD protein levels were assessed using flow cytometric analysis after staining with relevant primary and secondary antibodies, for both cell lines (SK-BR-3 and MCF-7) and both taxanes (paclitaxel and SB-T-1216) (data not shown).

\section{Effect of taxanes on the coimmunoprecipitation of caspase-2 and PIDD with RAIDD}

Coimmunoprecipitation (see "Materials and Methods") of RAIDD protein with other components of PIDDosome, i.e. PIDD protein and caspase-2, was assessed using subsequent western blot anylysis.

Both caspase- 2 and PIDD protein (detected by antibody against $\mathrm{C}$-form) were coimmunoprecipitated with RAIDD protein after 24-h incubation of SK-BR-3 cells with paclitaxel at the death-inducing concentration (100nM) (Figure 9).

Similarly, caspase-2 and PIDD protein were detected in coimmunoprecipitated complex with RAIDD protein in MCF-7 cells after $24 \mathrm{~h}$ incubation with paclitaxel at the death-inducing concentration (300 nM). Thus it seems that PIDDosome is formed in both SK-BR-3 and MCF-7 cells when taxane is applied at death-inducing concentrations.

\section{Effect of the inhibiton of RAIDD expression on taxane induced cell death}

Employing RNA interference (see "Materials and Methods"), we assessed the effect of specific inhibition of RAIDD expression on cell death induction after taxane application.

The inhibition of RAIDD expression by RNA interference was found to be highly efficient for both SK-BR-3 and MCF-7 cells (Figure 10A). Specific RAIDD siRNA did not significantly affect cell growth or survival in ether cell line (data not shown).

After $48 \mathrm{~h}$ as well as $96 \mathrm{~h}$ of incubation with paclitaxel at death-inducing concentration $(100 \mathrm{nM})$, the inhibition of RAIDD expression did not result in any significant change in the number of surviving SK-BR-3 cells (Figure 10B).

Similarly for MCF-7 cells, the inhibition of RAIDD expression did not result in any significant change in the number of surviving cells after $48 \mathrm{~h}$ and $96 \mathrm{~h}$ of incubation with paclitaxel at death-inducing concentration (300 nM) (Figure 10B).

\section{Discussion}

In our previous studies [7,14], we demonstrated that caspase-2 was significantly activated (up to 20-fold) along with other caspases (caspase-3, caspase- 9 and caspase-8) during apoptosis induction by taxanes in some cancer cells. We have also shown that, at least in some cases, the mitochondrial pathway does not represent the main pathway of apoptosis induction by taxanes. Recently, we found that apoptosis was induced by taxane application in SKBR-3 and MCF-7 breast cancer cells and that caspase-2 was also significantly activated in these cells. Furthermore, MCF-7 cells are without functional caspase-3, as we confirmed (data not shown). Thus it is reasonable to assume that caspase- 2 could play an important role in apoptosis induction by taxanes in breast cancer cells.

In order to study the role of caspase- 2 in apoptosis induction by taxanes in breast cancer cells, we employed a convenient model using SK-BR-3 and MCF-7 cells. SKBR-3 cells have nonfunctional p53 and functional caspase3 [39]. On the other hand, MCF-7 cells have functional p53, but they do not have functional caspase-3 [40]. The
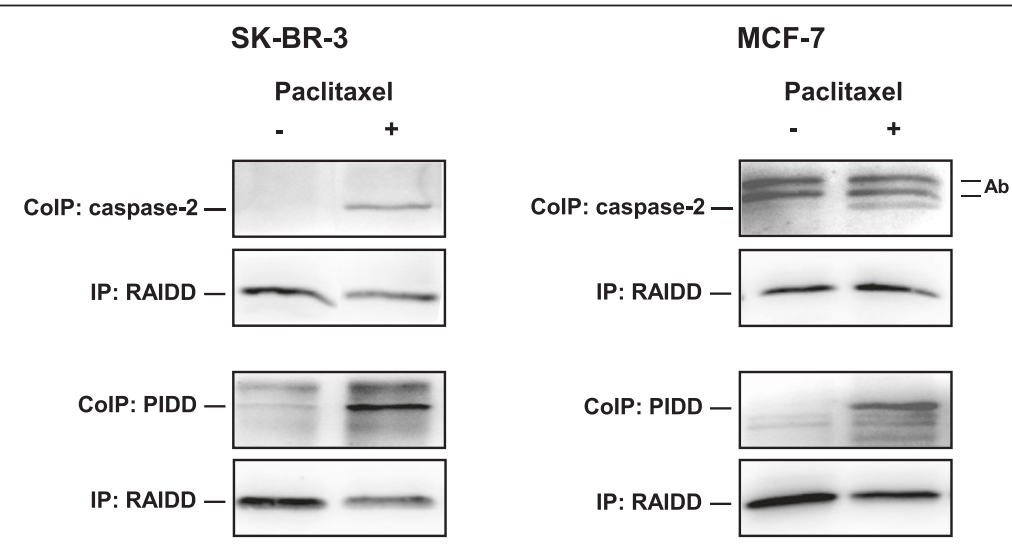

Figure 9 Effect of paclitaxel on coimmunoprecipitation of caspase-2 and PIDD with RAIDD in SK-BR-3 and MCF-7 cells. After $24 \mathrm{~h}$ of incubation with paclitaxel (100 nM for SK-BR-3 cells and 300 nM for MCF-7 cells), the level of precipitated RAIDD and coimmunoprecipitated caspase-2 as well as PIDD (detected by antibody against C-form) were determined using western blot analysis and relevant antibodies (see "Materials and Methods"). The heavy chain of the antibody used for RAIDD precipitation (Ab) is seen. The data shown were obtained in two independent experiments. 


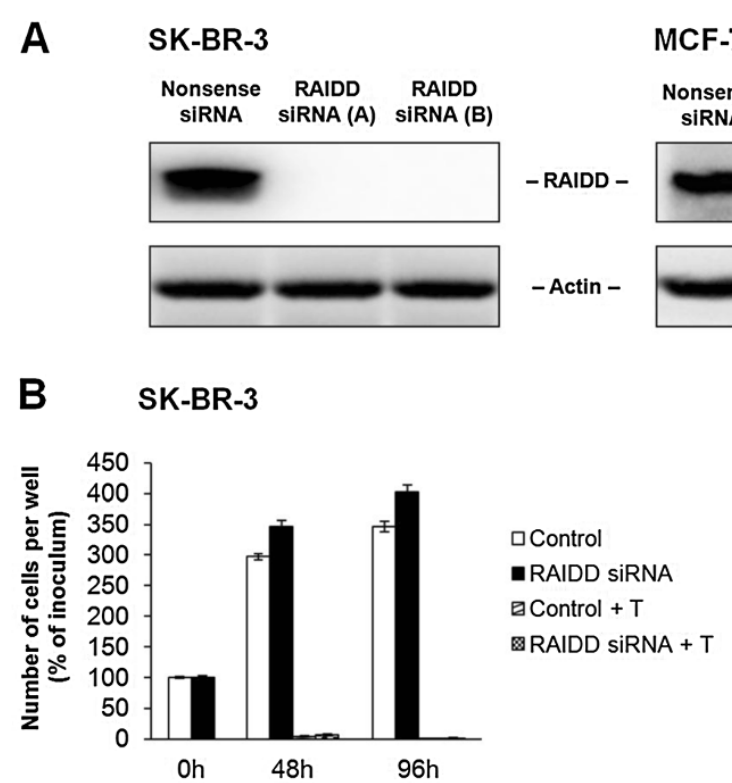

\section{MCF-7}

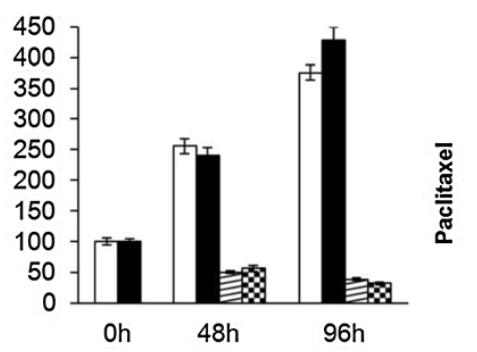

Figure 10 Effect of the inhibition of RAIDD expression on the growth and survival of SK-BR-3 and MCF-7 cells after paclitaxel treatment. (A) Efficiency of RAIDD suppression by two employed specific siRNA, i.e. A and B, in SK-BR-3 and MCF-7 cells is shown. Levels of RAIDD were determined using western blot analysis and relevant antibodies (see "Materials and Methods"). Actin levels were used to confirm equal protein loading. (B) The effect of specific RAIDD siRNA on the growth and survival of SK-BR-3 and MCF-7 cells after paclitaxel (T) treatment (100 nM for SK-BR-3 cells and $300 \mathrm{nM}$ for MCF-7 cells) is presented. The cells were seeded at $7 \times 10^{3}$ cells/200 $\mu$ l of medium per well and prepared as described (see "Materials and Methods"). After 0,48 and $96 \mathrm{~h}$ of incubation, the number of living cells was determined (see "Materials and Methods"). Each column represents the mean of 2 separate cultures \pm SEM.

use of these two cell lines, with their opposite properties, could help to elucidate the role of caspase-2 in apoptosis induction by taxanes. It could particularly contribute to our knowledge concerning the relationship between caspase- 2 activation and the activation of other caspases as well as the mechanism of caspase- 2 activation itself.

We tested both a classical taxane paclitaxel and a novel (second-generation) taxane SB-T-1216. In our previous study with MDA-MB-435 and NCI/ADR-RES cell lines [14], SB-T-1216 was shown to be more effective than paclitaxel, particularly in NCI/ADR-RES cells resistant to paclitaxel. However, SB-T-1216 and paclitaxel seemed to use the same or similar mechanism of cell death induction $[7,14]$. In this study, MCF-7 cells were shown to be a slightly more resistant to taxanes than SK-BR-3 cells but both cell lines showed similar sensitivity to paclitaxel and SB-T-1216 (see Figure 1). Furthermore, it seems that paclitaxel and SB-T-1216 use the same mechanism of apoptosis induction (see Figures 2, 3, 4, 5, 6 and "Results").

Significant activation of caspase-2 in SK-BR-3 and MCF-7 cells after taxane application at death inducing concentrations (see Figure 2) was confirmed using several different methods (see Figure 3). It is known that the measurement of caspase-2 activity can be affected by the activity of caspase-3 [41]. Thus, the measured activity of caspase-2 (see Figure 2) can be in fact a sum of caspase-2 and caspase- 3 activities. It can explain the discrepancy in timing of measured caspase- 2 activity (see Figure 2) and detected caspase-2 activation (see Figure 3). In MCF-7 cells, we only detected cleavage of procaspase-2 (see Figure $3 \mathrm{~A}$ ) under different conditions than procaspase- 2 was detected. However, the problem of detecting the cleaved form of caspase- 2 in MCF-7 cells could be a specific feature of these cells as described previously [42]. With regard to other cell types, several studies have demonstrated caspase-2 activation in various types of cancer cells after apoptosis induction by taxanes $[37,38,43]$.

Several studies with human prostate cancer cells, human melanoma cells and mouse embryonic fibroblasts have shown that caspase-2 is required for apoptosis induction by taxanes. These studies employed various techniques using siRNA, caspase- $2^{-/}$cells and specific caspase- 2 inhibitors $[21,23,44]$. We also demonstrated that caspase- 2 is required, at least partially, for apoptosis induction by taxanes in both studied breast cancer cell lines. The inhibition of caspase- 2 expression using siRNA technique resulted in a significantly increased number of surviving cells following application of taxanes at death-inducing concentrations. MCF-7 cells, with inhibited caspase-2 expression, grew even after application of death-inducing concentrations of taxanes (see Figure 4). This effect could 
not be attributed to the stimulatory effect of siRNA application on cell proliferation (see Figure 4B).

In spite of the fact that several studies have shown the involvement of caspase 2 in apoptosis induction by various stimuli in breast cancer cells $[27,34,35]$, the mechanism of caspase-2 involvement in apoptosis induction is not fully understood. Caspase- 2 has been described as an apical caspase [21,23] as well as a possible executioner caspase [45], in various types of cancer cells, together with its functions which are independent of apoptosis [46,47]. In this study with SK-BR-3 and MCF-7 cells we demonstrated that, together with caspase-2, other caspases (caspase-8, caspase-9, caspase-3, caspase-7) were activated after application of taxanes.

The activation of caspase- $9,-3$ and -7 was significantly affected in SK-BR-3 cells with inhibited caspase-2 expression after cell death induction by taxane application. While the cleavage of caspase-9 and caspase-3 significantly decreased, caspase-7 cleavage increased. In MCF-7 cells (without functional caspase-3) the cleavage of caspase- 9 was nearly blocked and the cleavage of caspase-7 was significantly decreased. Cleavage of caspase-8 decreased slightly in SK-BR-3 cells and significantly in MCF-7 cells (see Figure 5). The substantial inhibitory effect of the inhibition of caspase-2 expression on the activation of caspase- 8 and caspase-9, as well as the activation of executioner caspase-3 in SK-BR-3 cells and executioner caspase-7 in MCF-7 cells, supports a suggestion that caspase- 2 functions as an apical caspase. The increase of caspase- 7 activation together with the decrease of caspase- 3 activation, due to the inhibition of caspase-2 expression, in SK-BR-3 cells seems rather obscure (see Figure 5). Some kind of compensatory mechanism could be involved.

Additional information concerning caspase-2 function could come from testing the cleavage of caspase- 2 substrates. However, there are only a few known specific substrates of caspase-2 such as golgin-160 [31,46]. In this study, we demonstrated golgin-160 cleavage after application of death-inducing taxane concentrations in both studied cell lines (see Figure 3B). Unfortunately, it was not very helpful in elucidating caspase-2 function without data connecting golgin-160 cleavage to other relevant events.

Caspase- 2 has been found in the cytosol, Golgi complex, mitochondria and also in the nucleus of cells [46]. Regarding SK-BR-3 and MCF-7 cells, we showed that caspase-2 seemed to be primary localized in the nucleus. However, caspase-2 did not colocalize with DNA, as demonstrated with mitotic cells. Treating the cells with death-inducing taxane concentrations seemed to lead to a redistribution of caspase- 2 from the nucleus to the cytosol (see Figure 6). Caspase-2 was probably released from the nucleus because of the long-term disintegration of the nuclear envelope associated with the mitotic block after application of taxanes. The question, whether caspase- 2 is activated within the nucleus or in the cytoplasm, has not been answered yet [47]. In our case, long-term exposure of most of the cellular caspase- 2 to the cytoplasmic environment, which can comprise caspase-2-activating capacity, could lead to caspase- 2 activation. Thus, there could be a very simple explanation for caspase- 2 activation in breast cancer cells after taxane application.

Caspase-2 activation is usually connected with PIDDosome formation and PIDD protein upregulation via the induction of expression by activated p53 [23-25]. We found significant p53 activation assessed by the induction of $\mathrm{p} 21^{\mathrm{WAF} 1 / \mathrm{CIP} 1}$ expression, after the application of death-inducing taxane concentration in MCF-7 cells with functional p53 [48]. On the other hand, in SK-BR-3 cells without functional p53 [39] we confirmed that there was no p53 activity (see Figure 7). In the next step, we assessed the effect of taxanes on PIDD expression. No significant effect of taxanes on PIDD upregulation was found in either SK-BR-3 or MCF-7 cells (see Figure 8). This means that p53 activation, and the subsequent PIDD upregulation, is not involved in caspase-2 activation.

Nevertheless, we detected some coimmunoprecipitation of RAIDD protein with both PIDD protein and caspase-2 in both cell lines $24 \mathrm{~h}$ after taxane application at the death-inducing concentrations. However, suprisingly the inhibition of RAIDD expression using siRNA technique did not affect the number of surviving SK-BR-3 as well as MCF-7 cells after taxane application at all. Therefore, we suggest that PIDDosome formation [49] does not represent the main platform for caspase- 2 activation in breast cancer cells when apoptosis is induced by taxanes. Recently, other pathways of caspase- 2 activation which circumvent PIDDosome formation have been reported [50], e.g. the activation of caspase-2 in DISC complex [51]. Therefore other pathways of caspase- 2 activation in cells treated with taxanes should be considered.

\section{Conclusions}

We can summarize that significant caspase-2 activation is associated with apoptosis induction by taxanes in tested breast cancer cells and that caspase- 2 is required, at least partially, for the induction as well. Caspase-2 could be activated due its release from the nucleus and subsequent long-term exposure to the cytoplasmic environment after taxane application resulting in longterm disintegration of the nuclear envelope. Concerning the mechanism of caspase- 2 activation, caspase-2 seems to be activated via other mechanism than PIDDosome formation. The activation of both initiator and executioner caspases after taxane application depends on caspase- 2 expression. Thus we can suggest that caspase-2 functions as an apical caspase in apoptosis induction by taxanes. 


\section{Materials and methods Materials}

Paclitaxel was obtained from Sigma-Aldrich (St. Louis, MO, USA). SB-T-1216 [13] was synthesized at the Institute of Chemical Biology and Drug Discovery (Stony Brook, NY, USA). Taxanes were dissolved in DMSO (tissue culture quality) to obtain a $1 \mathrm{mM}$ stock solution.

For western blot analysis, the following primary antibodies were used: mouse monoclonal antibody against caspase-3 (\#9668), rabbit antibody against cleaved caspase-3 (\#9661), rabbit antibody against cleaved caspase-7 (\#9491), mouse monoclonal antibody against caspase-8 (\#9746), and rabbit antibody against cleaved caspase-9 (\#9505) from Cell Signaling Technology (Danvers, MA, USA), rat monoclonal antibody against caspase-2 (ALX-804-355-C100) and mouse monoclonal antibody against PIDD (ALX-804-837) from Enzo Life Science (Farmingdale, NY, USA), rabbit monoclonal antibody against caspase-2 (ab32021), rabbit polyclonal antibody against caspase-2 (ab 18737), goat polyclonal antibody against golgin-160 (anti-GOLGA3, ab40837), and rabbit monoclonal antibody against RAIDD (Ab52621) from Abcam (Cambridge, UK), rabbit polyclonal antibody against caspase-2 (H-145, sc-15379), mouse monoclonal antibody against p21 (F-5, sc-6246), goat polyclonal antibody against PIDD (S-17, sc-32161), and rabbit polyclonal antibody against PIDD (H-300, sc-2354) from Santa Cruz Biotechnology (Santa Cruz, CA, USA), and mouse monoclonal antibody against actin (AC-40, A3853) from SigmaAldrich.

For precipitation, Protein A/G PLUS- agarose beads (sc-2003) from Santa Cruz Biotechnology were used.

\section{Cells and culture conditions}

Human breast carcinoma cell lines SK-BR-3 and MCF-7 were obtained from American Type Culture Collection (ATCC) (Rockville, MD, USA) and National Cancer Institute (Frederick, MD, USA). The cells were maintained in a culture medium at $37^{\circ} \mathrm{C}$ in a humidified atmosphere of $5 \% \mathrm{CO}_{2}$ in air. The culture medium consisted of basic medium supplemented with $10 \%$ heat-inactivated fetal bovine serum (Biochrom AG, Berlin, Germany). The basic medium was RPMI 1640 medium (Sigma-Aldrich, St. Louis, MO, USA) containing extra L-glutamine $(300 \mu \mathrm{g} / \mathrm{ml})$, sodium pyruvate $(110 \mu \mathrm{g} / \mathrm{ml})$, HEPES $(15 \mathrm{mM})$, penicillin $(100 \mathrm{U} / \mathrm{ml})$ and streptomycin $(100 \mu \mathrm{g} / \mathrm{ml})$, as previously described [52].

\section{Assessment of cell growth and survival}

Cells were harvested and seeded at $20 \times 10^{3}$ cells $/ 100 \mu \mathrm{l}$ of culture medium into the wells of a 96-well plastic plate. After 24-h preincubation period allowing cells to attach, the culture medium was replaced by either the culture medium without taxane (control) or with one of tested taxanes (paclitaxel or SB-T-1216) at desired concentrations. Cell growth and survival were evaluated after $96 \mathrm{~h}$ of incubation. The number of living cells was determined using a hemocytometer after staining with trypan blue [53].

\section{Measurement of caspase- 2 activation}

A commercial CaspGLOW ${ }^{m}$ Active Caspase Staining Kit (Biovision, Mountain View, CA, USA) was used to detect the active form of caspase-2, as previously described [54]. Cells (approximately $3 \times 10^{5}$ cells per sample) were seeded and after a 24-h preincubation period allowing cells to attach, the culture medium was replaced by either taxane-free culture medium (control) or with medium containing taxane (paclitaxel or SB-T-1216) at desired concentrations. After the required incubation period, the cells were harvested using low-speed centrifugation and staining was performed according to the manufacturer's instructions. Fluorescence was measured using a FACS Calibur cytometer (Becton Dickinson, San Jose, CA, USA).

\section{Real-time PCR}

Cells were harvested and seeded at $1.2 \times 10^{6}$ cells $/ 6 \mathrm{ml}$ of the culture medium into Petri dishes. After a 24-h preincubation period, the culture medium was either replaced by taxane-free culture medium (control) or with medium containing taxane (paclitaxel or SB-T-1216) at desired concentrations. Total RNA was isolated from SK-BR-3 and MCF-7 cells using a RNAeasy MiniKit (Qiagen, Hilden, Germany) according to the manufacturer's instructions after the required incubation period.

Prepared RNA was reverse transcribed using a TaqMan Reverse Transcription Reagents kit (Applied Biosystems, Foster City, CA, USA) with random primers, in accordance with the manufacturer's instructions. Transcribed cDNA was subjected to real-time quantitative PCR in an ABI Prism 7000 Sequence Detection System (Applied Biosystems) using a commercially available TaqMan Gene Expression Master Mix kit (Applied Biosystems) with TaqMan Gene Expression Assays (Applied Biosystems) for CDKN1A (cyclin-dependent kinase inhibitor 1A, p21), PIDD (p53-induced death domain protein), CASP2 (caspase-2) and for GAPDH (glyceraldehyde 3-phosphate dehydrogenase) as the control gene. All data were normalized relative to the amount of GAPDH cDNA in the sample and the $2^{-\Delta \Delta \mathrm{Ct}}$ method was used to calculate relative changes in genes expression using ABI Prism 7000 SDS Software Version 1.1 (Applied Biosystems).

\section{Western blot analysis}

Cells (approximately $1 \times 10^{7}$ cells per sample) were seeded and taxanes were applied after 24 -h preincubation. Cells were harvested after the incubation period by low-speed centrifugation, washed in PBS and centrifuged. Cell pellets 
were stored at $-80^{\circ} \mathrm{C}$. Frozen pelets were resuspended in RIPA buffer (Sigma Aldrich, St. Louis, MO, USA) containing a mixture of protease inhibitors (Sigma Aldrich). The protein lysate was centrifuged $(14,000 \mathrm{rpm}, 20 \mathrm{~min}$, $4^{\circ} \mathrm{C}$ ) and the supernatant was stored at $-20^{\circ} \mathrm{C}$.

Western blot was carried out with some modifications as has been previously described in detail [4]. Proteins separated by SDS-PAGE were blotted onto $0.2 \mu \mathrm{m}$ nitrocellulose membrane PROTRAN BA 83, (WhatmanSchleicher and Schuell, Maidstone, UK) for $3 \mathrm{~h}$ at 0.25 A, using a MiniProtean II blotting apparatus (Bio-Rad, Hercules, CA). The membrane was blocked with 5\% nonfat milk or 5\% BSA in TBS for 15 min. TBS containing Tween-20 (0.1\%) was used for washing. The washed membrane was incubated with the primary antibody. Following incubation (overnight, $4^{\circ} \mathrm{C}$ ), the membrane was washed (three times) and then incubated for 1-2 $\mathrm{h}$ with the corresponding horseradish peroxidaseconjugated secondary antibody (Santa Cruz Biotechnology, Santa Cruz, CA, USA). Afterward, the membrane was washed three times and the chemiluminescence signal was detected using a Supersignal West Pico Chemiluminescence Substrate from Pierce (Thermo Fisher Scientific Inc., Rockford, IL, USA) and and the KODAK Gel Logic 1500 Imaging System (Eastman Kodak Company, Rochester, NY, USA).

\section{RNA interference}

In order to optimize the RNA interference procedure, two independent siRNAs targeting the caspase-2 mRNA sequence, i.e. MISSION ${ }^{\circ}$ esiRNA human CASP2 (Sigma Aldrich, St. Louis, MO, USA) and CASP2 siRNA (s2412, Applied Biosystems, Foster City, CA, USA), and two independent siRNA targeting the RAIDD mRNA sequence, i.e. two CRADD (RAIDD) Silencer ${ }^{\circ}$ Select siRNAs (s16654 and s225028, Applied Biosystems, Foster City, CA, USA), were tested. Two different transfection agents, i. e. INTERFERin ${ }^{\text {tw }}$ (Polyplus transfection ${ }^{\mathrm{me}}$, Illkirch, France) and siPORT ${ }^{\mathrm{Tx}}$ NeoFX ${ }^{\mathrm{m} x}$ Transfection Agent (Applied Biosystems) were also tested. We used GAPDH siRNA (Applied Biosystems) as a positive transfection control and Silencer Negative Control siRNA (Applied Biosystems) as the non-targeting siRNA. The efficiency of caspase- 2 and RAIDD inhibition was tested after 48-h incubation of cells with a medium containing transfection mixture for mRNA levels (real-time PCR, data not shown) and after 72-h incubation for protein levels (western blot analysis, Figure 4A). The efficiency of caspase-2 and RAIDD inhibition reached similar levels using any combination of the two tested transfection agents and the two siRNAs. For experiments, INTERFERin ${ }^{\text {tw }}$ transfection agent (Polyplus transfection ${ }^{\mathrm{Tm}}$ ), CASP2 siRNA (Applied Biosystems) and CRADD (RAIDD) siRNA s225028 (Applied Biosystems) were used.
Based on the manufacturer's instructions (INTERFERin ${ }^{\mathrm{Tu}}$ in vitro siRNA Transfection Protocol, Polyplus transfection $^{\mathrm{ns}}$ ) we performed RNA interference in SK-BR-3 and MCF-7 cells. The cells were seeded at $7 \times 10^{3}$ cells $/ 200 \mu \mathrm{l}$ of culture medium into a 96-well plate or at $7 \times 10^{4}$ cells/ $2 \mathrm{ml}$ of culture medium into a12-well plate for 24-h preincubation. The siRNA was diluted in OPTI-MEM ${ }^{\circ}$ I Reduced Serum Medium (Gibco, Invitrogen ${ }^{\mathrm{m}}$ Life Technologies, Carlsbad, CA, USA) for a final concentration of $5 \mathrm{nM}$ siRNA. INTERFERin ${ }^{\mathrm{m}}$ transfection agent $(0.75 \mu \mathrm{l}$ per 96 -well and $4 \mu \mathrm{l}$ per 12-well) was added. The mixture was incubated for $10 \mathrm{~min}$ at room temperature to form the transfection complex. Preincubation medium in wells was replaced by fresh culture medium $(150 \mu \mathrm{l}$ in 96 -well plates and $1 \mathrm{ml}$ in 12-well plates). Prepared transfection complex was added to fresh culture medium in cultivation wells and gently mixed. Cells were incubated with the medium containing transfection complex for $72 \mathrm{~h}$. After incubation, the medium containing transfection complex was replaced with the culture medium containing tested taxane at the death inducing concentration for further analyses.

\section{Confocal microscopy}

Cells were seeded onto coverslips (approximately $2 \times 10^{5}$ cells per coverslip) and taxanes were applied after $24 \mathrm{~h}$ of preincubation as described above (see "Measurement of caspase-2 activation"). After $36 \mathrm{~h}$ of incubation for SKBR-3 and $60 \mathrm{~h}$ of incubation for MCF-7, cells were fixed with $4 \%$ paraformaldehyde for $15 \mathrm{~min}$ at $37^{\circ} \mathrm{C}$ and permeabilized with $0.1 \%$ Triton X-100 in 4\% paraformaldehyde for $15 \mathrm{~min}$. After washing with PBS, cells were blocked with Image-i $T^{\mathrm{Tm}}$ FX signal enhancer (Molecular Probes, Invitrogen, Eugene, OR, USA) for $30 \mathrm{~min}$. Next, cells were washed with PBS and stained with $30 \mu \mathrm{l}$ of the primary antibody against caspase-2 (H-145, Santa Cruz Biotechnology, Santa Cruz, CA, USA or ab18737, Abcam, Cambridge, UK), diluted 1:50 in PBS, at $4^{\circ} \mathrm{C}$ overnight. Cells were than washed with PBS and incubated with $30 \mu \mathrm{l}$ of Alexa Fluor 488 goat anti-rabbit secondary antibody (Molecular Probes), diluted 1:200 in PBS, for 1 hour in a dark at room temperature. Finally, cells were washed again with PBS. Stained cells on coverslips were transferred onto a droplet of Vectashield Mounting Medium with DAPI (Vector Laboratories, Burlingame, CA, USA) and sealed. Samples were analyzed using a Leica TCS SP5 confocal microscope (Bannockburn, IL, USA) using a $63 \times$ oil objective at relevant excitation and emission wavelengths.

\section{Immunoprecipitation}

First, $25 \mu \mathrm{l}$ of agarose beads coated with bacterial proteins A and G (sc-2003) from Santa Cruz Biotechnology (Santa Cruz, CA, USA) were washed (resuspended in $0.5 \mathrm{ml}$ of lysis buffer and centrifuged at $5000 \mathrm{rpm}$, 
$1 \mathrm{~min}$ ) four times and finally resuspended in $0.5 \mathrm{ml}$ of lysis buffer. $3.3 \mu \mathrm{l}$ of anti-RAIDD (see "Materials") antibody was added to the beads and mixture was incubated for $4 \mathrm{~h}$ in a refrigerator. Beads with bound antibody were washed as described and supernatant was removed. Beads with bound antibody were stored at $4^{\circ} \mathrm{C}$.

Cell were harvested (see "Western blot analysis") and lysed by non-denaturing lysis buffer (1\% NP-40, $20 \mathrm{mM}$ TRIS pH 7.4, $1 \mathrm{mM}$ EDTA, 5\% glycerol, $250 \mathrm{mM} \mathrm{NaCl}$ ). Cell lysates were incubated for $20 \mathrm{~min}$ on ice and then centrifuged $\left(14,000 \mathrm{rpm}, 15 \mathrm{~min}\right.$.) at $4^{\circ} \mathrm{C}$. Supernatants containing cell proteins were stored on ice and protein concentrations were assessed.

Beads with bound antibody were diluted (to final volume of $100 \mu \mathrm{l}$ ) in lysate buffer containing $300 \mu \mathrm{g}$ of cell proteins. The mixture was incubated overnight while agitated. After incubation, the mixture was centrifuged (6500 rpm, $7 \mathrm{~min}$ ) and supernatant was discarded. Beads with bound immunocomplexes were washed twice as described with lysis buffer and twice with $50 \mathrm{mM}$ Tris $\mathrm{HCl}$ $\mathrm{pH}$ 7.5. Washed beads with bound immunocomplexes were finally resuspended in $40 \mu \mathrm{l}$ of sample buffer (see "Western blot analysis") and heated for $15 \mathrm{~min}$ at $75^{\circ} \mathrm{C}$ to disintegrate the beads and release the immunocomplexes. $15 \mu \mathrm{l}$ of the samples were loaded on $15 \%$ polyacrylamide gel for Western blot analysis (see "Western blot analysis").

\section{Statistical analysis}

Statistical significance of difference was determined using the Student's $t$-test. $\mathrm{P}<0.05$ and $\mathrm{P}<0.01$ were considered statistically significant at the $5 \%$ and $1 \%$ levels, respectively.

\section{Competing interests}

The authors declare that they have no competing interests.

\section{Authors' contributions}

$\mathrm{MJ}$ carried out western blot experiments and worked on the manuscript, KB carried out real-time PCR experiments and siRNA techniques, DK participated in western blot experiments and in coimmunoprecipitation, VNF carried out confocal microscopy, JŠ participated in coimmunoprecipitation, JF carried out flow cytometry analysis of caspases-2 activity, IZ and IO participated in the preparation of SB-T-1216 taxane, JK coordinated the experiments and helped to complete the manuscript. All authors read and approved the final manuscript.

\section{Acknowledgments}

This work was supported by grant 301/09/0362 from the Grant Agency of the Czech Republic (to J.K.), by research project PRVOUK P27 from the Charles University in Prague (to J.K.), and by grant CA 103314 from the National Cancer Institute, USA (to I.O.). The authors thank Mr. Thomas Secrest for English revision.

\section{Author details}

'Department of Cell and Molecular Biology, Third Faculty of Medicine, Charles University, Ruská 87, 100 00, Prague 10, Czech Republic. ${ }^{2}$ Institute of Chemical Biology and Drug Discovery, State University of New York at Stony Brook, Stony Brook, NY, USA.

Received: 18 January 2013 Accepted: 1 May 2013

Published: 15 May 2013

\section{References}

1. Choy H: Taxanes in combined modality therapy for solid tumors. Crit Rev Oncol Hematol 2001, 37:237-247.

2. Galletti E, Magnani M, Renzulli ML, Botta M: Paclitaxel and docetaxel resistance: molecular mechanisms and development of new generation taxanes. Chem Med Chem 2007, 2:920-942.

3. Ojima I, Slater JC, Michaud E, Kuduk SD, Bounaud PY, Vrignaud P, Bissery MC, Veith JM, Pera P, Bernacki RJ: Syntheses and structure-activity relationships of the second-generation antitumor taxoids: exceptional activity against drug-resistant cancer cells. J Med Chem 1996, 39:3889-3896.

4. Ehrlichová M, Koc M, Truksa J, Nad’ová Z, Václavíková R, Kovár J: Cell death induced by taxanes in breast cancer cells: cytochrome $C$ is released in resistant but not in sensitive cells. Anticancer Res 2005, 25:4215-4224.

5. Ferlini C, Raspaglio G, Mozzetti S, Cicchillitti L, Filippetti F, Gallo D, Fattorusso C, Campiani G, Scambia G: The seco-taxane IDN5390 is able to target class III beta-tubulin and to overcome paclitaxel resistance. Cancer Res 2005, 65:2397-2405.

6. Ojima I, Chen J, Sun L, Borella CP, Wang T, Miller ML, Lin S, Geng X, Kuznetsova L, Qu C, Gallager D, Zhao X, Zanardi I, Xia S, Horwitz SB, MallenStClair J, Guerriero JL, Bar-Sagi D, Veith JM, Pera P, Bernacki RJ: Design, synthesis, and biological evaluation of new-generation taxoids. J Med Chem 2008, 51:3203-3221.

7. Voborillová J, Němcová-Fürstová V, Neubauerová J, Ojima I, Zanardi I, Gut I, Kovár J: Cell death induced by novel fluorinated taxanes in drug-sensitive and drug-resistant cancer cells. Invest New Drugs 2011, 29:411-423.

8. Spencer CM, Faulds D: Paclitaxel. A review of its pharmacodynamic and pharmacokinetic properties and therapeutic potential in the treatment of cancer. Drugs 1994, 48:794-847.

9. Orr GA, Verdier-Pinard P, McDaid H, Horwitz SB: Mechanisms of taxol resistance related to microtubules. Oncogene 2003, 22:7280-7295.

10. Xiao $H$, Verdier-Pinard P, Fernandez-Fuentes N, Burd B, Angeletti R, Fiser $A$, Horwitz SB, Orr GA: Insights into the mechanism of microtubule stabilization by Taxol. Proc Natl Acad Sci USA 2006, 103:10166-10173.

11. Jordan MA, Ojima I, Rosa F, Distefano M, Wilson L, Scambia G, Ferlini C: Effects of novel taxanes SB-T-1213 and IDN5109 on tubulin polymerization and mitosis. Chem Biol 2002, 9:93-101.

12. Fan W: Possible mechanisms of paclitaxel-induced apoptosis. Biochem Pharmacol 1999, 57:1215-1221.

13. Aoudjit F, Vuori K: Integrin signaling inhibits paclitaxel-induced apoptosis in breast cancer cells. Oncogene 2001, 20:4995-5004.

14. Kovár J, Ehrlichová M, Smejkalová B, Zanardi I, Ojima I, Gut I: Comparison of cell death-inducing effect of novel taxane SB-T-1216 and paclitaxel in breast cancer cells. Anticancer Res 2009, 29:2951-2960

15. Das GC, Holiday D, Gallardo R, Haas C: Taxol-induced cell cycle arrest and apoptosis: dose-response relationship in lung cancer cells of different wild-type p53 status and under isogenic condition. Cancer Lett 2001, 165:147-153.

16. Sano D, Matsuda $H$, Ishiguro $Y$, Nishimura G, Kawakami M, Tsukuda M: Antitumor effects of IDN5109 on head and neck squamous cell carcinoma. Oncol Rep 2006, 15:329-334.

17. Drago-Ferrante R, Santulli A, Di Fjord R, Giuliano M, Calvaruso G, Tesoriere G, Vento R: Low doses of paclitaxel potently induce apoptosis in human retinoblastoma Y79 cells by up-regulating E2F1. Int J Oncol 2008, 33:677-687.

18. Mediavilla-Varela M, Pacheco FJ, Almaguel F, Perez J, Sahakian E, Daniels TR, Leoh LS, Padilla A, Wall NR, Lilly MB, De Leon M, Casiano CA: Docetaxel-induced prostate cancer cell death involves concomitant activation of caspase and lysosomal pathways and is attenuated by LEDGF/p75. Mol Cancer 2009, 8:68.

19. von Haefen C, Wieder T, Essmann F, Schulze-Osthoff K, Dörken B, Daniel PT: Paclitaxel-induced apoptosis in $B J A B$ cells proceeds via a death receptor-independent, caspases-3/-8-driven mitochondrial amplification loop. Oncogene 2003, 22:2236-2247.

20. Iwanaga N, Kamachi M, Aratake K, Izumi Y, Ida H, Tanaka F, Tamai M, Arima K, Nakamura H, Origuchi T, Kawakami A, Eguchi K: Regulation of alternative splicing of caspase-2 through an intracellular signaling pathway in response to pro-apoptotic stimuli. J Lab Clin Med 2005, 145:105-110.

21. Mhaidat NM, Wang Y, Kejda KA, Zhang XD, Hersey P: Docetaxel-induced apoptosis in melanoma cells is dependent on activation of caspase-2. Mol Cancer Ther 2007, 6:752-761.

22. Zhivotovsky B, Orrenius S: Caspase-2 function in response to DNA damage. Biochem Biophys Res Commun 2005, 331:859-867. 
23. Ho LH, Read SH, Dorstyn L, Lambrusco L, Kumar S: Caspase-2 is required for cell death induced by cytoskeletal disruption. Oncogene 2008, 27:3393-3404

24. Tinel A, Tschopp J: The PIDDosome, a protein complex implicated in activation of caspase- 2 in response to genotoxic stress. Science 2004, 304:843-846.

25. Baptiste-Okoh N, Barsotti AM, Prives CA: Role for caspase 2 and PIDD in the process of p53-mediated apoptosis. Proc Natl Acad Sci USA 2008, 105:1937-1942.

26. Cuenin S, Tinel A, Janssens S, Tschopp J: p53-induced protein with a death domain (PIDD) isoforms differentially activate nuclear factor-kappa $B$ and caspase-2 in response to genotoxic stress. Oncogene 2008, 27:387-396.

27. Mansilla S, Priebe W, Portugal J: Mitotic catastrophe results in cell death by caspase-dependent and caspase-independent mechanisms. Cell Cycle 2006, 5:53-60.

28. Manzl C, Krumschnabel G, Bock F, Sohm B, Labi V, Baumgartner F, Logette E, Tschopp J, Villunger A: Caspase-2 activation in the absence of PIDDosome formation. J Cell Biol 2009, 185:291-303.

29. Dass CR, Galloway SJ, Choong PF: Dz13, a c-jun DNAzyme, is a potent inducer of caspase-2 activation. Oligonucleotides 2010, 20:137-146.

30. Thomas CG, Strom A, Lindberg K, Gustafsson JA: Estrogen receptor beta decreases survival of p53-defective cancer cells after DNA damage by impairing $\mathrm{G}_{2} / \mathrm{M}$ checkpoint signaling. Breast Cancer Res Treat 2011, 127:417-427.

31. Mancini M, Machamer CE, Roy S, Nicholson DW, Thornberry NA, CasciolaRosen LA, Rosen A: Caspase-2 is localized at the Golgi complex and cleaves golgin-160 during apoptosis. J Cell Biol 2000, 149:603-612.

32. Lassus $P$, Opitz-Araya $X$, Lazebnik $Y$ : Requirement for caspase-2 in stress-induced apoptosis before mitochondrial permeabilization. Science 2002, 297:1352-1354.

33. Enoksson M, Robertson JD, Gogvadze V, Bu P, Kropotov A, Zhivotovsky B, Orrenius S: Caspase-2 permeabilizes the outer mitochondrial membrane and disrupts the binding of cytochrome $\mathrm{c}$ to anionic phospholipids. J Biol Chem 2004, 279:49575-49578.

34. Chen $\mathrm{H}$, Chung S, Sukumar S: HOXA5-induced apoptosis in breast cancer cells is mediated by caspases 2 and 8. Mol Cell Biol 2004, 24:924-935.

35. Das S, Nwachukwu JC, Li D, Vulin Al, Martinez-Caballero S, Kinnally KW, Samuels $\mathrm{HH}$ : The nuclear receptor interacting factor-3 transcriptional coregulator mediates rapid apoptosis in breast cancer cells through direct and bystander-mediated events. Cancer Res 2007, 67:1775-1782.

36. Luparello C, Sirchia R, Lo Sasso B: Midregion PTHrP regulates Rip1 and caspase expression in MDA-MB231 breast cancer cells. Brest Cancer Res Treat 2007, 111:461-474.

37. Wang YF, Chen CY, Chung SF, Chiou YH, Lo HR: Involvement of oxidative stress and caspase activation in paclitaxel-induced apoptosis of primary effusion lymphoma cells. Cancer Chemother Pharmacol 2004, 54:322-330.

38. Fabbri F, Amadori D, Carloni S, Brigliadori G, Tesei A, Ulivi P, Rosetti M, Vannini I, Arienti C, Zoli W, Silvestrini R: Mitotic catastrophe and apoptosis induced by docetaxel in hormone-refractory prostate cancer cells. J Cell Physiol 2008, 217:494-501.

39. Papanikolaou V, Iliopoulos D, Dimou I, Dubos S, Tsougos I, Theodorou K, Kitsiou-Tzeli S, Tsezou A: The involvement of HER2 and p53 status in the regulation of telomerase in irradiated breast cancer cells. Int J Oncol 2009, 35:1141-1149.

40. Friedrich K, Wieder T, Von Haefen C, Radetzki S, Jänicke R, Schulze-Osthoff K, Dörken B: Daniel, PT: Overexpression of caspase- 3 restores sensitivity for drug-induced apoptosis in breast cancer cell lines with acquired drug resistance. Oncogene 2001, 20:2749-2760.

41. Maillard MC, Brookfield FA, Courtney SM, Eustache FM, Gemkow MJ, Handel RK, Johnson LC, Johnson PD, Kerry MA, Krieger F, Meniconi M, MuñozSanjuán I, Palfrey JJ, Park H, Schaertl S, Taylor MG, Weddell D, Dominguez C: Exploiting differences in caspase-2 and -3 Sz subsites for selectivity: structure-based design, solid-phase synthesis and in vitro activity of novel substrate-based caspase-2 inhibitors. Bioorg Med Chem 2011, 19:5833-5851.

42. Yang S, Thor AD, Edgerton S, Yang X: Caspase-3 mediated feedback activation of apical caspases in doxorubicin and TNF-alpha induced apoptosis. Apoptosis 2006, 11:1987-1997.

43. Yuan SY, Hsu SL, Tsai KJ, Yang CR: Involvement of mitochondrial pathway in Taxol-induced apoptosis of human T24 bladder cancer cells. Urol Res 2002, 30:282-288.
44. Luo Y, Ling Y, Guo W, Pang J, Liu W, Fang Y, Wen X, Wei K, Gao X: Docetaxel loaded oleic acid-coated hydroxyapatite nanoparticles enhance the docetaxel-induced apoptosis through activation of caspase- 2 in androgen independent prostate cancer cells. J Control Release 2010, 147:278-288.

45. Samraj AK, Sohn D, Schulze-Osthoff K, Schmitz I: Loss of caspase-9 reveals its essential role for caspase-2 activation and mitochondrial membrane depolarization. Mol Biol Cell 2007, 18:84-93.

46. Vakifahmetoglu-Norberg $\mathrm{H}$, Zhivotovsky B: The unpredictable caspase-2: what can it do? Trends Cell Biol 2010, 20:150-159.

47. Kitevska T, Spencer DM, Hawkins CJ: Caspase-2: controversial killer or checkpoint controller? Apoptosis 2009, 14:829-848.

48. Han J, Kim S, Yang JH, Nam SJ, Lee JE: TPA-induced p21 expression augments G2/M arrest through a p53-independent mechanism in human breast cancer cells. Oncol Rep 2012, 27:517-522.

49. Tinel A, Janssens S, Lippens S, Cuenin S, Logette E, Jaccard B, Quadroni M Tschopp J: Autoproteolysis of PIDD marks the bifurcation between pro-death caspase-2 and pro-survival NF-kappaB pathway. EMBO J 2007, 26:197-208.

50. Kim IR, Murakami K, Chen NJ, Saibil SD, Matysiak-Zablocki E, Elford AR, Bonnard M, Benchimol S, Jurisicova A, Yeh WC, Ohashi PS: DNA damage- and stress-induced apoptosis occurs independently of PIDD. Apoptosis 2009, 14:1039-1049.

51. Olsson M, Vakifahmetoglu H, Abruzzo PM, Högstrand K, Grandien A Zhivotovsky B: DISC-mediated activation of caspase-2 in DNA damage-induced apoptosis. Oncogene 2009, 28:1949-1959.

52. Kovář J, Valenta T, Štýbrová H: Differing sensitivity of tumor cells to apoptosis induced by iron deprivation in vitro. In Vitro Cell Dev Biol Anim 2001, 37:450-458.

53. Musílková J, Kovár J: Additive stimulatory effect of extracellular calcium and potassium on non-transferrin ferric uptake by HeLa and K562 cells. Biochim Biophys Acta 2001, 1514:117-126.

54. Němcová-Fürstová $V$, James RF, Kovár J: Inhibitory effect of unsaturated fatty acids on saturated fatty acid-induced apoptosis in human pancreatic $\beta$-cells: activation of caspases and ER stress induction. Cell Physiol Biochem 2011, 27:525-538

doi:10.1186/1475-2867-13-42

Cite this article as: Jelínek et al:: Caspase- 2 is involved in cell death induction by taxanes in breast cancer cells. Cancer Cell International 2013 $13: 42$

\section{Submit your next manuscript to BioMed Central and take full advantage of:}

- Convenient online submission

- Thorough peer review

- No space constraints or color figure charges

- Immediate publication on acceptance

- Inclusion in PubMed, CAS, Scopus and Google Scholar

- Research which is freely available for redistribution 